\title{
MELIT㤅A PHAETON
}

About the first of July I was informed by Mr. W. E. Saunders that silu.iy before, when out on one of his Ornithological and Botanical excusions, he had secn Melitaa phaeton, in a cedar swamp, wo miles from Kcmoka station, which is ten miles west of London, on the Grancl 'Irunk line. I took the firsi farourable opporumicy of getaing a signi of that insect alive, which occurred on the ninth. I found the swamp, and soon saw the butterfies disporting themselves in the sunny spots, secming.) quiie plentiful. They would not have been difficult to sccure hack the footing been solid, but a previous heavy rain had set that afloat. I took five, and saw quite as many more during the short stay $I$ made in the roods.

J. Alstox Mioffat.

\section{CORRESPONDENCE.}

\section{PETROPHORA SIIATEATA.}

Dear Sirs At our recent annual gathering the Rev. T. W. Fyles hat brought with him a box of insects for the purpose of obtaining their names if he could. Amongst them was a Geometer, which 1 recognized as identical with one $I$ have had for four years awaiting a name. When Captain Geddes arrived he also had another of the same kind amongst the material which he had brought. As no cluc to its identity could bo (b)tained from the authors we consulted, I thought the time had now arrived when we ought to know something about it, so 1 applicd at headquarters for information, going into communication with the Rer. Geo. D. Hulst, who kindly returned my specimen with the namo Petrophora silaceata, Hub. It proves to be an exceedingly interesting species, widespread and variable. Mr. Hulst mentioned that one of his specimens is from Labrador, sent to him by Mocschler. As I could not find the name in any of our N. $\Lambda$. Catalouges, I turned to the European, and found it in Edward Newman's "Illustrated Natural History of British Moths" as Cidaria silaceata, Hub. It is therein illustrated by figures of six well defined varieties. Newman does not give any variety names, but Mr. Hulst determines my specimen to be "var. deflavala, Stdgr.," yet it is not identical with any of Newman's figures, although closely resembling the sixth, which is one of the least ornate. Newman says: "The moth appears in May, and a second brood in August, and is regarded as common in England, Scotland and Ireland.'

London, Dec. 18th, 1891.

J. Alston Moffat. 